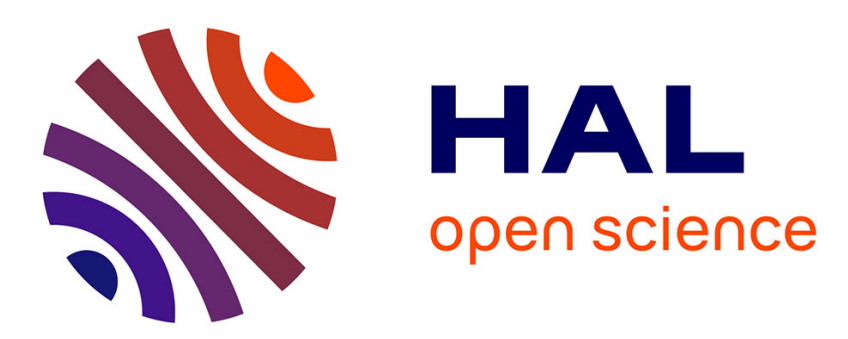

\title{
Genetic screening as a technique of government: The case of neonatal screening for cystic fibrosis in France
} Joëlle Vailly

\section{To cite this version:}

Joëlle Vailly. Genetic screening as a technique of government: The case of neonatal screening for cystic fibrosis in France. Social Science and Medicine, 2006, 63, pp.3092 - 3101. 10.1016/j.socscimed.2006.07.025 . hal-01082117

\section{HAL Id: hal-01082117 https://hal.science/hal-01082117}

Submitted on 12 Nov 2014

HAL is a multi-disciplinary open access archive for the deposit and dissemination of scientific research documents, whether they are published or not. The documents may come from teaching and research institutions in France or abroad, or from public or private research centers.
L'archive ouverte pluridisciplinaire HAL, est destinée au dépôt et à la diffusion de documents scientifiques de niveau recherche, publiés ou non, émanant des établissements d'enseignement et de recherche français ou étrangers, des laboratoires publics ou privés. 


\title{
Genetic screening as a technique of government:
}

\section{The case of neonatal screening for cystic fibrosis in France}

\author{
Joëlle Vailly* \\ *Inserm, Institut de recherche interdisciplinaire sur les enjeux sociaux (Iris, CNRS, Inserm, \\ EHESS, Université Paris 13), Bobigny, France
}

This text has been published in: Vailly, J. 2006. Genetic screening as a technique of government: The case of neonatal screening for cystic fibrosis in France. Social Science and Medicine, 63 (12), 3092-3101.

\begin{abstract}
The biomedicalization process and the rise of genetics that have occurred in the last decades involve political issues concerning subjects in biomedicine who are in a position to act and make choices. My work examines these issues through a study of the process by which neonatal screening for the genetic disease of cystic fibrosis was set up in France. Making use of the Foucauldian notion of government, which implies power relations among entities recognized as subjects of action, I examine how different agents (or groups) came to form either governing or governable entities within this health policy, and by what means government in this area is exercised. The study positions relations between governors and the governed in the dynamic specific to them, showing that screening for cystic fibrosis is to a large degree a political technique for governing self and others based on a biomedical technique. Two types of subjects (a professional association and a patients' association) are seen to be constituted in different ways and endowed with more or less extensive power. More generally, the study raises the question of the form of the political, through the example of genetic screening.
\end{abstract}




\section{Introduction}

The health policies that began to emerge in northern countries in the eighteenth century had farther-reaching objectives than before: it was no longer a matter of merely eliminating disease but also preventing it (Foucault, 1994). On a practical level, this shift led to developing and using statistics about populations and diseases, and to a series of interventions affecting lifestyles and living conditions, as well as to the practice of screening $a$ priori normal populations. With the deployment of surveillance medicine in the second half of the twentieth century, the amount of screening increased substantially (Armstrong, 1995). This medicalization movement, whereby the field of medical intervention, its authority and practices were greatly extended, has more recently evolved into a process of biomedicalization strongly marked by integration of new scientific technology (Clarke, Mamo, Fisman, Shim, \& Fosket, 2003). In this context, the genetic approach has worked to outline a new form of knowledge that has modified theories, discourses, and biomedical objects. Proponents of this approach sometimes go so far as to claim that the truth of a human being is inscribed in his or her genes, ${ }^{i}$ though the increasingly apparent limitations of this kind of "genetics is all" understanding, underestimating as it does the complexity of living beings, seem now to be undermining this viewpoint (Fox Keller, 2000). Neonatal genetic screening is part of the biomedicalization process and as such has been developing rapidly. This should not surprise us given that the family-child complex was the first target of medical jurisdiction and that infants have long been a preferred focus of health policies (Foucault, 1994). While in the United States the number of diseases screened for at birth varies by state, some states test for up to 43 diseases, most of genetic origin, using a new technique called tandem mass spectrometry (ACMG, 2005). In France five diseases are tested for at birth, including cystic fibrosis [mucoviscidose in French] since January 2002 when the country opted to generalize neonatal screening for this disease. ${ }^{\text {ii }}$ 
There are two fundamental characteristics of neonatal screening for cystic fibrosis. First, in the absence of a cure for the disease, screening for it has given rise to a debate in the biomedical arena (Grosse, Boyle, Botkin, Comeau, Kharrazi, Rosenfeld et al., 2004), as there are differentiated evaluations of the relation between advantages (namely, proper nutrition for patients and an end to diagnostic confusion) and disadvantages (namely, risk of crosscontamination and false positives). The existence of this debate explains in part why neonatal screening for the disease is not more widespread. Until recently, it was limited to France, nearly all of Australia and New Zealand, certain regions of the United States and Great Britain. ${ }^{\text {iii }}$ Second, it is the first screening program in France to mobilize molecular biology instruments at a mass scale. France's cystic fibrosis screening program involves a complex sequence of procedures: briefly, first, the level in the blood of the protein immunoreactive trypsin is tested; if the test is positive DNA mutation is looked for; the definitive diagnosis is then made on the basis of chloride level in sweat. Because it makes use of both classic techniques (the sweat test has been used since the 1950s) and recent ones (the mutations associated with cystic fibrosis were first tested for in the 1990s) that are part of different socio-historical stages of the disease (Kerr, 2005), neonatal screening for cystic fibrosis is exemplary of certain current developments in biomedicine, where DNA study is becoming increasingly ordinary (Clarke, Mamo, Fisman, Shim, \& Fosket, 2003).

Underlining the theoretical contribution of Georges Canguilhem's work, Foucault (1994) explained that when geneticists and biologists look for mutations, they make themselves knowing subjects while taking life itself as their object. Human beings become rational subjects who can modify themselves as living beings ${ }^{\text {iv }}$ and establish a circuit between subject and object. In addition to the philosophical aspects of this, the idea of a balance between subject and object echoes certain political questions that may be formulated as follows: What "subject" is in a position to make choices? Who is the "object" of public 
policies? The position of acting subjects in biomedicine has been the focus of several studies in the social sciences, which purport to show the limitations of their position or, on the contrary stress their influence. Some researchers have emphasized the determinism effect produced by "geneticization" (Lippman, 1992), the passivity and fatalism inherent in the idea that the future is inescapably inscribed in our genes (Nelkin, 1996; Senior, Marteau, \& Peters, 1999). More recently, other researchers have claimed that patient collectives are full-fledged actors in genetic research (Rabeharisoa \& Callon, 1999). Still others, while rejecting the idea of any sharp distinction between power and subjectivity, have suggested that what we are seeing is a new form of subjectivation, expressed in matters of genetic testing by the notions of responsibility, choice, and wishes (Lemke, 2004; Novas \& Rose, 2000; Rose, 2001). At a more general level, the vision of people as passive in the face of technology has been replaced in the last few years by a more dynamic image, wherein their responses to new technology range from acceptance to rejection or indifference (Lock \& Kaufert, 1998). Lastly, and more broadly than in biomedicine, study of the "gouvernement des corps" (government of bodies) has allowed for analyzing the type of subject produced by policies touching on life or the living being, in a framework defined not only by the law but also and to an equal degree by norms and values (Fassin \& Memmi, 2004). The present study takes up the notion of government to see what light it sheds on the new genetics-related policies.

To preclude all misunderstanding, it should be specified that Foucault (1994) defined his notion of "government" as the set of more or less conscious and calculated modes of action that act on other individuals' action possibilities. In this sense, government refers not only to political structures and management by the state, but to a way of structuring others' eventual field of action. It implies a power relation, exercised on another who is recognized and maintained as a subject of action, and it includes strategies and instruments for governing others. Analyzing an instance of government therefore presupposes studying types of 
governing agents and governed agents, the way the entity to be governed is conceived, the techniques used to govern, and the ends sought (Dean, 1999). These aspects are of course interrelated because the way of acting and shaping behavior fashions the types of subject, and subjects are themselves in a position to condition these techniques.

I am concerned in this study with the influence of genetics on the way we conduct our lives - i.e., how we conduct ourselves and how others influence our conduct - by looking at the history and practices of neonatal screening for cystic fibrosis in France. Specifically, I examine how different agents become governing or governable individuals (or groups) and by what means and instruments government is exercised. The first part of this article presents the study and the methodology used. The second part shows the subtle power relations between professionals and non-professionals in the history of neonatal screening for cystic fibrosis in France: the influence of professionals is notable and there has been a generally fragmented conception of practices. In the third part I present and analyze one of the major arguments that worked in favor of choosing neonatal screening for cystic fibrosis in France, showing that screening was in part conceived as a tool for governing patients in time and space. While I am fully aware how likely it is for political and scientific issues to be interrelated, in this text I concentrate on the political side of the problem; I do not look into the truth regimes cited in scientific and medical arguments either in favor of cystic fibrosis screening or against it, as this would extend beyond the scope of this article.

\section{Presentation of the study}

To answer the questions raised above, I conducted a qualitative study from 2002 to 2004 that further developed an earlier study in which I retraced the history and issues involved in setting up a regional cystic fibrosis screening program in Brittany in the late 1980s. This earlier study brought to light the fact that the arguments that had been used by 
pediatricians and biologists worked to legitimate screening in this region and had widerranging effects, resonating with action outside the biomedical sector proper, in a section of the Breton population (anonymous reference for referees). On the basis of this first study I was also able to begin identifying the national officials involved in cystic fibrosis screening in France and get a sense of their positions on the screening program. For the national-level section of the project, I conducted 25 semi-directive interviews using the snowball method. I interviewed heads of the Association Française pour le Dépistage et la Prévention des Handicaps de l'Enfant (AFDPHE, the French association for screening for and preventing handicaps in children), the professional association in charge of neonatal screening in France, as well as persons in charge of the patients' association named "Vaincre la Mucoviscidose" (VLM; Winning against cystic fibrosis). The interviews included exchanges with representatives in charge of neonatal screening in the relevant funding and political authorities: the Caisse Nationale d'Assurance-Maladie des Travailleurs Salariés (CNAMTS; permanent employee health insurance bureau, the public authority that finances France's universal health insurance program) and the French Ministry of Health. Early on in the survey process, I hypothesized that consistent its own public claims, the patient association had played a major role in the decision to extend neonatal screening for cystic fibrosis to the whole of France; in other words, that its members had acted as subjects of biomedicine. ${ }^{\mathrm{v}} \mathrm{My}$ second hypothesis was that the time dimension and the aim of getting persons with cystic fibrosis taken in charge as early as possible in their lives had played a central role in the decision. In addition to the knowledge of this domain that I had acquired through the first, regional-level field study, I prepared for the interviews by attentively (re)reading approximately fifteen national and international biomedical articles on neonatal screening for cystic fibrosis; this enabled me to identify potentially controversial points. The interview method consisted first of establishing respondents' specific occupational or associative 
itineraries and their interacquaintance network in the area of cystic fibrosis. In the exchange that followed respondents were asked to 1) give an account of the history of the decisionmaking process and the setting up of the screening program in which they would identify what they considered the major stages (important meetings, changes in actors' viewpoints, etc.); 2) identify the arguments in favor of screening in France, particularly those that had been crucial to the decision to generalize screening. Lastly, I was particularly attentive to relations and mutual influences among biomedical professionals, non-professional actors, and health administration officials. As the work progressed, a number of documents related to neonatal screening for cystic fibrosis were made available to me (reports, AFDPHE information bulletins, archives, etc.); these constituted supporting material for the interview discourse. Interviews lasted on average two hours and were conducted in respondent's place of work. Respondents' names have been omitted here. With respondents' consent, all interviews were recorded and transcribed in full.

\section{Professional association, patients' association}

The driving force behind neonatal screening in France was a small group of pediatricians and geneticists who in the 1970s were already launching screening for phenylketonuria, first on a few newborns, then on the entire neonatal population ${ }^{\mathrm{vi}}$. In 1978 , these professionals, who had united to form the above-cited Association Française pour le Dépistage et la Prévention des Handicaps de l'Enfant (AFDPHE), set about organizing neonatal screening and established an agreement with the CNAMTS funding institution. The association gradually acquired legitimacy in the eyes of the CNAMTS, who saw it as an effective source of assistance in preventing diseases that, though rare, are totally debilitating. The arrangement presented the advantage of lowering costs (association leaders worked on a volunteer basis), and the professionals could be relied on to set up the program with all the 
necessary care and rigor. Moreover, the association could claim that it had prevented thousands of children from being afflicted with serious handicaps. With its single representative within the association, the French ministry of health can be said to have accompanied this movement rather than guiding it. When in 2000 the AFDPHE presented its case to the CNAMTS for adding cystic fibrosis to the list of diseases screened for, citing studies by a group of experts the association had brought together (essentially pediatricians and geneticists), the CNAMTS readily agreed to fund the program, for the estimated sum of $€ 2 \mathrm{~m}$ per year. In December 2000 the two partners held a joint press conference to announce the launching of the program. At this moment, too, various commissions that included different actors (primarily biologists and pediatricians, but also a CNAMTS representative, a legal specialist, and others) were set up to work out how best to implement the policy. ${ }^{\text {vii }}$

What may be learned from this brief overview of the way roles and powers were initially distributed in this health policy? Studying the way a program of screening for cystic fibrosis carriers was set up in Denmark in the 1990s, Koch and Stemerding (1994) proposed the term "regime" to designate mutually adapted and coordinated technological, organizational and societal practices as a result of earlier processes of attunement between technological options, demand and acceptability. In a similar spirit, the already established regime of neonatal screening for disease in France facilitated the emergence and acceptability of neonatal screening for cystic fibrosis, since it was based on the same types of technical organization and social interaction as already existed in France. Furthermore, just as in the Danish program the national health policy authority was not the driving force in setting up the screening program, so the case of the AFDPHE is indicative of a domain - health - in which, historically, a plurality of means have been used to handle medical problems, means often furnished by agents other than the state and ranging from benevolent associations to scientific societies (Foucault, 1994). Generally, as has been pointed out, the state is more likely to 
intervene in the administration of bodies in an accompanying role than as an order-giver (Fassin \& Memmi, 2004), in contrast to its dominating role in other areas, such as security. Here the particularity of the AFDPHE resided in the fact that since it was in charge of both pushing forward and setting up neonatal screening, it was the single depositary of the sum of policies in this field - the result of what was actually a delegation of power.

While the professional association played a crucial role in setting up generalized screening for cystic fibrosis, it must also be understood how screening was apprehended by its promoters; that is, how they conceived of this instance of government. Rose (2001) has underlined that the major role of professional associations and ethics committees in biomedical practices as they concern prenatal diagnosis involves a particular type of "pastoral power," one not oriented toward the population at large but rather targeting individuals "at risk." "viii What kind of power is post-natal intervention constructed on, when there can no longer be any accusation of eugenics? What kind of relation between power focused on individual bodies and a policy meant to cover the population as a whole is such power based on?

The interviews I conducted with members of the AFDPHE working group attest to differentiation among biomedical actors by practice (those who followed up on patients/those who didn't) and evaluation of neonatal screening (seen to involve primarily beneficial medical effects/seen more broadly to involve problems, such as informing parents, false positives, etc.). ${ }^{\text {ix }}$ The first of these positions is attested by the following statement from a clinician-pediatrician and active AFDPHE member: "It seems to me that among health professionals dealing with cystic fibrosis ... I have no memory of anyone saying, 'No, it's not worth it.' ... For my part, I urged them to do it. When I talked to [X, who took the second position] about it, I'd say, "You don't know what it is to have people come in with kids age 4, 5 [that are not being followed] — it shouldn't be like that... You start off with a statistics thing, 
but very soon you're dealing with a family." The second type of position is expressed in the following statement from another respondent, also a pediatrician, what the clinicians called a "screener"; in other words, someone "who's really got the screening mindset": "The problem is that people only talk about medical evaluation, they forget all the rest. Evaluating is not just saying that the patient is doing fine or not doing fine or doing a bit better; it also means looking at the problems you might have created, the costs, everything there is around that action, informing parents, etc. ... in the given population." The type of medicine argued for depended on whether the actor followed patient "cases," as in one group, or was involved in policy technology focused on the population at large. Overall, there were more professionals in the first category, and they were clearly more likely to favor screening than the second type; this illustrates how preventive policy applied to a population at large can actually be based on a case-by-case approach. Even applied to a given population at large-newbornsgeneralized screening thus preserved the aspect of pastoral power that emphasizes the individual and considers the "flock" as such a secondary concern. This orientation should be linked to the history of French medicine, more strongly marked by power focused on the individual and the individual's body and behavior than on policy techniques covering the population at large - in contrast to English medicine, for example (Foucault, 1994). This way of conceiving government produced a fragmentation effect which in this case was intensified by the role of the patient association, "Vaincre la mucoviscidose".

"Vaincre la mucoviscidose" (VLM) was first created in the 1960s on the initiative of doctors and a few families under the name Association Française de Lutte Contre la Mucoviscidose (French association for combating cystic fibrosis). The association has nearly 4500 members today, a third of whom are families and adult patients while two-thirds are sympathizers. It is organized around a Conseil d'Administration (CA, administrative board) made up primarily of families, patients, and sympathizers, and a Conseil Médical (CM, 
medical board) together with a Conseil Scientifique (CS, scientific board). The association itself was the locus of a subtle power game between professionals and non-professionals. Up until the late 1990s, screening for cystic fibrosis was not an association priority, and the CA followed the overall negative opinion of the $\mathrm{CM}$ in the matter, as it was understood to be the best informed and the most competent to judge. While administrators did occasionally make decisions which diverged from the opinions of their "expert advisors," cystic fibrosis screening did not seem to them a justifiable priority. But in 1999, when the AFDPHE was working on the question of whether screening was advisable and how to implement it, the patients' association's CA was shifting its view: it was now in favor of cystic fibrosis screening. Under the influence of one of its new non-medical directors, the administrative board saw this as the moment to unite energies within the association and bring cystic fibrosis to the attention of the state authorities. Moreover, the idea that gradually germinated was to work for improvement in care and follow-up for persons with cystic fibrosis, as may be seen from the following statement from this new director who is not the parent of a sick child: "I said [to the members of the CA], 'I wonder if the setting up of neonatal screening for cystic fibrosis might not be a good way for the association to further develop strategically.' ... [Later] I said; 'If we can manage to demonstrate to France and the French that this is a public health problem, we can put your disease on stage, as it were ... The second point is that all of this only makes sense if it brings improved treatment for you. ... You can influence how treatment is organized." As we shall see, this last point can be linked to the thinking of some of the professionals. In fact, the convergence of viewpoints among the different actors had much to do with the fact that several members of the patient association $\mathrm{CM}$ were also members of the AFDPHE working group. When the funding authority inquired into the patient association's opinion of screening, it was able to confirm that it was in favor. In fact, this association actively lobbied the public authorities by means of various political officials, 
positioned either within the ministries or outside; it thus played the role of pressure group, with the hired help of a "lobbying office" to more readily open doors. As explained, the health ministry of the time was not influential in the decision to screen, but it did become a frontline player in reorganizing cystic fibrosis treatment procedures, as we shall see.

"Vaincre la Mucoviscidose" thus played a mixed role; my initial hypothesis of its central role in the decision to generalize neonatal screening for cystic fibrosis was not confirmed. One of the members most active in running the association expressed this quite clearly: "It's Y [head of the AFDPHE] who deserves the credit for neonatal cystic fibrosis screening in France. If Y hadn't tackled the problem with such energy and devotion ... I'd still be there [trying to get screening generalized]." The association members had of course acted at certain moments as subjects, i.e., they had "acted on others' action" (that of the political authorities), but often as subjects under medical influence. Association policy on cystic fibrosis screening was determined at least as much by the $\mathrm{CM}$ as by the non-professionals. It would be overestimating the autonomy and role of patient associations to think that the example of other diseases such as myopathies (Rabeharisoa \& Callon, 1999) applied here. Still, the association did manage to elicit the interest of the political authorities, and in this sense it did manage to make itself heard. Its influence, though of only relative importance, raises the question of the meaning of the political in our societies. The effect of their lobbying attests to a political power which once again displaced its center of interest toward individuals or groups of individuals (an association) rather than toward the population at large and as such.

This part of the study allowed me to identify the main governing entities, the power relations obtaining among them, and the way they conceived of screening. I now had to examine the techniques of government. 


\section{Governing in space and time}

Above and beyond the scientific and medical debate, two arguments were decisive for the emergence of consensus in France, a consensus operative within the group of professionals set up by the AFDPHE, between the overseeing institutions (CNAMTS, ministry of health), and among association leaders.

First, there was serious concern about the moment in life at which the diagnosis was made. The diagnosis was thought to come too late in France though, before implementation of neonatal screening, two-thirds of children were diagnosed before the age of one. ${ }^{\mathrm{x}}$ Some professionals explained that patients diagnosed at the age of six or seven might already have undergone serious health damage due to the fact that the disease was not well known enough among healthcare givers and the patient had not been adequately followed. This understanding was expressed by a pediatrician participating in the AFDPHE working group: "Neonatal screening enables us to make an early diagnosis. The fact is that a third of children were diagnosed after age one and $15 \%$ over age 10 . Diagnoses were made extremely late, and there were children who arrived with one lung already virtually destroyed."

As previously mentioned, one of the striking developments in medicine in the last two centuries has been to induce a reconfiguration of the timeframe of disease. Disease used to be treated after symptoms appeared; now the idea was to anticipate and prevent. It was no longer a matter of waiting for what the future might bring but of transforming the future through new behavior in the present (Armstrong, 1995; Foucault, 1994). We should probably go further and observe that here the idea was to discover the disease as early as possible: the race against disease began at birth. This was consistent with my hypothesis on the importance of the time dimension as a vector for diffusion of neonatal screening. It must also be noted that this result does not seem to fit into the Foucaldian analytic framework: while that analysis does encompass historical processes, Foucault attributed much more importance to space than time 
in his reading of developments in the second half of the twentieth century. ${ }^{\mathrm{xi}}$ Yet as we shall see, space-related questions were also clearly relevant.

Generally speaking, since the emergence of hospital medicine the new medical timeframe has gone together with a new spatial one: disease is no longer expressed by external symptoms but located in the depths of organs and the substance of tissues (Armstrong, 1995; Foucault, 1963). In fact, as my interviews brought out, one major effect of neonatal screening for cystic fibrosis was a redistribution in space, one that no longer concerned the disease but the patients themselves. The idea that gradually emerged was to associate screening with patient follow-up in specialized treatment centers using standardized protocols instead of leaving treatment up to doctors who encountered at most a few cases of cystic fibrosis in the course of their careers and whose follow-up procedures could only be heterogeneous. For half of the persons interviewed, the plan to have patients treated in centers that would use a standardized protocol and follow enough patients to confer a specific competence on the health care professionals who treat this rare disease was a condition for generalizing screening; there was no point to cystic fibrosis screening unless this kind of patient follow-up was also guaranteed. As a pediatrician and member of the AFDPHE working group explained: "We all agreed that if there was no obligatoin to set up a specialized center to manage it - though at the beginning this wasn't as clear-cut as it became later-it wasn't worth doing. Because [otherwise] everyone's going to handle things his own way in his own little space, and we need coherence." A CNAMTS official expressed the same idea: "The CNAMTS accord specified very clearly that we didn't want to set up systematic screening without the guarantee of a good treatment and follow-up for the children. That was really a condition for setting up the screening." The other half of my respondents, including a majority of AFDPHE working group members, took this reasoning further, to the point where they reversed the logical order: in their opinion, screening was a mode for inducing 
professionals to follow standardized treatment rules, and above all a means of improving treatment. It was necessary to remedy practice heterogeneity and dispersion of treatment structures; cystic fibrosis screening was the stage that had to be gone through to improve patient care quality. A pediatrician and member of the working group explained: "I defended the screening program by saying that neonatal screening was a means of handling the problem of cystic fibrosis. ... Screening was a means of getting protocole regulated care and follow-up established in treatment centers." Another pediatrician and AFDPHE official specified the import of this argument: "It wasn't screening for screening's sake, with direct or indirect arguments ... no. In France this category of patients was not well cared for or followed, and this was the occasion to learn it [how to take charge of them]. If we hadn't had that I don't think we would've done it."

In 2000-2001, when it was a stated government priority to ensure equal treatment for patients throughout the country, the health ministry went beyond what the leaders of the AFDPHE were proposing, officially announcing the creation of Centres de Ressources et de Compétence de la Mucoviscidose (CRCMs, Cystic fibrosis resource and expertise centers), multidisciplinary specialized centers that would fulfill a specific set of functions. ${ }^{\text {xii }}$ Better yet, the ministry itself funded the centers in two installments of $€ 4.6$ million each and ensured the creation of permanent jobs in them. Meanwhile the new directors of the CRCMs organized themselves into the "Fédération des CRCM," later the Société Française de la Mucoviscidose. As an administrative structure and scientific society, this association was the guarantor of a certain scientific and medical legitimacy. Screening thus came to mean acting to improve patients' health and well-being by means of a biomedical technique; the effect was to structure the way patient treatment was organized, centralize that treatment, receive funds, and ensure legitimacy. 
It may rightly be observed that screening for a genetic disease made the patient population more captive than it had been: biomedical technique was now being used to manage patient populations. The fact that neonatal cystic fibrosis screening in France was therefore also in part an instrument for orienting patients in space should not surprise us if we remember that medicine has historically been an art of spatial distribution, requiring the resolution of such questions as hospital location, cemetery displacement, separation of patients likely to contaminate each other, etc. (Foucault, 1994). This approach of course has political implications in terms of power. As Foucault (1994) pointed out, "When it becomes possible to analyze knowledge in terms of region, area, implantation, displacement, transfer, we can grasp the process by which knowledge functions as power and reactivates the effects of power". It would be a gross exaggeration and hardly to our purposes to reduce this health policy to a power strategy on the part of the professionals. It could not be called a deliberate, preconceived strategy, but rather a technique for guiding and "framing" professionals and orienting patients, a technique invented during the process. In fact, the regional cystic fibrosis screening program in Brittany had already made use of this argument, among many others, in the late 1980s (anonymous reference for referees). However, the screening policy did indeed have power effects, in the form of an increased cohort of patients followed in the centers, funding and jobs allocated to those centers, the new visibility of the disease, etc. The hypothesis has been put forward that cystic fibrosis screening gave rise to national decisions that strengthened the dynamic in favor of a "sub-specialization in cystic fibrosis" within the pediatric specialization process (Frattini \& Naiditch, 2004). My results show that above and beyond any professional dynamic, what was invented was an art of governing. The history of cystic fibrosis screening retraces the genesis of a technique applied both to one's own conduct, in that a medical collective was enjoined to follow protocols, and the conduct of others, i.e., cystic fibrosis patient families, who were now led to bring their children to 
specialized centers. Compared to the classic meaning of the word government, however, government of "oneself" here pertains to a collective "self": rather than an inquiry into one's own individual behavior, the aim was to affect practices within the medical collective one belonged to.

\section{Conclusion}

By way of conclusion three remarks. The first concerns the impact of genetics, the second the analytics of government, and the third, a specific implication of government.

Between a fantasy of genetics as a force that is transforming altogether our way of conceiving of life, our human capacities, handicaps, social problems, family relations, and quality of life, and an understanding that denies any impact at all to genetics, Richards (2001) has proposed a nuanced analysis that points up the consequences of genetics as they derive directly from practices. With regard specifically to cystic fibrosis, Kerr (2005), after presenting the different techniques and ideas that shaped our conception of this disease from the 1940s to the present, argued against the claim that genetics has radically modified that conception. This raises the question of what genetics has changed or is changing in health policy on cystic fibrosis. My earlier work brought to light that the genetics approach of looking for mutations helped make neonatal screening for cystic fibrosis acceptable in France because it was used in such a way as to increase the specificity of tests and limit the number of parents unnecessarily made to worry about their children's health (author's reference). Screening has here in turn been analyzed as a governing technique. Genetics indirectly played a role in the emergence of a mode of government based on a biomedical technique. It worked to legitimate a health policy that centralized treatment and had power effects.

The history of how screening was set up in France shows the decisive role of professionals as full-fledged acting subjects. The patient association intervened more 
peripherally and had no decision-making function, though its intervention was real; it functioned as a pressure group. It is also necessary to specify what is meant by "patient" association given that close study of who was actually implicated in the association reveals that the role played by the its medical advisors was at least as important as that of the nonprofessionals. These two sets of persons established relations of mutual influence, strengthened by the fact of double professional membership, a situation which in turn created a relatively limited network of experts. It is important that the general image created by these influences and the existence of this network not be one of a flattened, non-hierarchically organized social micro-world with everyone at the same level; that would be to compress the thickness of power relations in an analytic approach to government that would look only for relations between free subjects. On the other hand, this analytics allows us to reposition distinctions between the governing and the governed within their own specific dynamic (some groups may be in control at certain moments, then lose that control) and to study how the different types of subjects were constituted differently (the professional association to which power was delegated and the pressure group are each endowed with a specific type of power).

One of the ways I will further develop this research is by studying what local procedures come into play in the transmission of government all the way to the level of maternity wards. Before newborns are screened in France, parents are asked for their consent, and at least in legal terms, they have a certain degree of maneuvering room. As Fassin (2000) proposes in a text on the politics and policies of living beings and life, the point is to "study health as both a signified and a signifyer of social change; that is, for the meanings it bears and the signs its manifests of those meanings." In a screening policy that appears in some respects quite consensual - it is, after all, a matter of treating suffering children — one of the issues would seem to be the form taken by the political. It is important to be clear about the 
ways that conceptions of the individual and the collective, power relations, types of domination, and spaces of freedom may be linked to each other.

\section{References}

\section{Bibliography}

Armstrong, D. (1995). The rise of surveillance medicine. Sociology of Health \& Illness, 17(3), 393-404.

Clarke, A.E., Mamo, L., Fisman, J.R., Shim, J.K., \& Fosket, J.R. (2003). Biomedicalization: technoscientific transformations of health, illness, and U.S. biomedicine. American Sociological Review, 68, 161-194.

Dean, M. (1999). Governmentality: power and rule in modern society. London, Thousan Oaks, New Delhi: Sage.

Fassin, D. (2000). Entre politiques du vivant et politiques de la vie. Anthropologie et sociétés, 24(1), 95-116.

Fassin, D., \& Memmi, D. (2004). Le gouvernement des corps. Paris: Editions de l'Ecole des hautes études en sciences sociales.

Foucault, M. (1963). Naissance de la clinique. Paris: Presses Universitaires de France.

Foucault, M. (1994). Dits et écrits II, 1976-1988. Paris: Gallimard.

Fox Keller, E. (2000). The century of the gene. Cambridge: Harvard Century Press.

Frattini, M.-O., \& Naiditch, M. (2004). Mucoviscidose, spécialisation en médecine et dépistage néonatal systématique. Sciences Sociales et Santé, 22(4), 61-71.

Gilbert, W. (1992). A vision of the grail. In D. Kevles, \& L. Hood (Eds.), The code of codes (pp. 83-97). Cambridge: Harvard University Press. 
Grosse, S.D., Boyle, C.A., Botkin, J.R., Comeau, A.M., Kharrazi, M., Rosenfeld, M., \& Wilfond, B.S. (2004). Newborn screening for cystic fibrosis. Evaluation of benefits and risks and recommendations for state newborn screening programs. Recommendations and Reports 53(RR-13), 1-36.

Kaufert, P.A. (2000). Screening the body: the pap smear and the mammogram. In M. Lock,A. Young, \& A. Cambrosio (Eds.), Living and working with the new medical technologies. Intersections of inquiery (pp. 165-183). Cambridge: Cambridge University Press.

Kerr, A. (2005). Understanding genetic disease in a socio-historical context: a case-study of cystic fibrosis. Sociology of Health \& Illness, 27(7), 873-896.

Koch, L., \& Stemerding, D. (1994). The sociology of entrenchment: a cystic fibrosis test for everyone? Social Science \& Medicine, 39(9), 1211-1220.

Lemke, T. (2004). Disposition and determinism - genetic diagnostics in risk society. The Sociological Review, 52(4), 550-566.

Lippman, A. (1992). Led (astray) by genetic maps: the cartography of the human genome and health care. Social Science \& Medicine, 35(12), 1469-1476.

Lock, M., \& Kaufert, P.A. (1998). Pragmatic women and body politics. Cambridge: Cambridge University Press.

Nelkin, D. (1996). The politics of predisposition. The social meaning of predictive biology. In A. Heller,S. Puntscher Rieckmann, \& F. Fehér (Eds.), Biopolitics. The politics of the body, race and nature (pp. 133-142). Aldershot: Avebury.

Novas, C., \& Rose, N. (2000). Genetic risk and the birth of the somatic individual. Economy and Society, 29(4), 485-513.

Rabeharisoa, V., \& Callon, M. (1999). Le pouvoir des malades. L'association Française contre les myopathies et la recherche. Paris: Editions de l'Ecole des mines. 
Richards, M. (2001). How distinctive is genetic information? Studies in History and Philosophy of Biological and Biomedical Sciences, 32(4), 663-687.

Rose, N. (2001). The politics of life itself. Theory, Culture \& Society, 18(6), 1-30.

Senior, V., Marteau, T.M., \& Peters, T.J. (1999). Will genetic testing for predisposition for disease result in fatalism? A qualitative study of parents' responses to neonatal screening for familial hypercholesteroleamia. Social Science \& Medicine, 48(12), 1857-1860.

Stockdale, A. (1999). Waiting for the cure: mapping the social relations of human gene therapy research. Sociology of Health \& Illness, 21(5), 579-596.

Vailly, J. (2004). Une politique de santé "a priori": le dépistage néonatal de la mucoviscidose en Bretagne. Sciences Sociales et Santé, 22(4), 35-60.

\section{Documents}

ACMG (2005). Newborn screening: toward a uniform screening panel and system. Report of the American College of Medical Genetics.

NNSGRC (2006). U.S. National Screening Status Report. Report of the National Newborn Screening and Genetics Resource Center.

ONM (2002). Rapport sur la situation de la mucoviscidose en 2000. Rapport de l'Observatoire national de la mucoviscidose (Institut national d'études démographiques, Vaincre la mucoviscidose).

VLM (1999). Plus vite, plus loin. Rapport annuel de Vaincre la Mucoviscidose. 
${ }^{\mathrm{i}}$ In this connection we may quote Gilbert (1992), winner of the Nobel Prize in Chemistry whose work led to determining DNA sequences: "Three billion bases of sequences can be put on a single compact disk (CD), and one will be able to pull a CD out of one's pocket and say, 'Here is a human being; it's me!'”

${ }^{\text {ii }}$ Cystic fibrosis is usually characterized by severe respiratory and digestive disorders due to the accumulation of viscous mucus, though the severity of these disorders varies greatly and their occurence is unpredictable. Life expectancy in France for a person with cystic fibrosis is approximately 37 years.

iii Today, a good many states in the US practice neonatal cystic fibrosis screening (NNSGRC, 2006) and Great Britain plans to generalize it in 2007. For information on the British program, see in particular the site of the Institute of Child Health: www.ich.ucl.ac.uk/.

${ }^{\text {iv }}$ Pointing out that human beings can do this does not mean that they do do it, especially given the generalized prohibition against human transgenesis that may be transmitted to descendants. Though genetic therapy clinical trials that introduce genes into patients' chromosomes that are not transmitted to descendants raise a series of conceptual and technical difficulties (Stockdale, 1999), these trials do attest to humans'ability to modify themselves genetically as living beings.

v The association's annual report for 1999 specified: "In full agreement with the AFDPHE, the AFLM [former association acronym] is presently engaged in all necessary procedures and lobbying of the CNAMTS and the Health Ministry bureau [in order to participate in organizing neonatal screening for cystic fibrosis]" (VLM, 1999).

${ }^{\text {vi }}$ Phenylketonuria screening stands as a highly successful example of neonatal screening: newborns with the disease are immediately given appropriate nutrition, thereby preventing otherwise unavoidable mental retardation.

vii AFDPHE archives show that the procedure for detecting mutations was developed by one of these commissions. Using a study of mutation distribution in France's various regions, the commission first tested a variety of detection kits available on the market, ultimately choosing to recommend one that recognizes 20 mutations and covers $82 \%$ of mutations found in France. It also requested the provider to find a means of extending the capacities of the kit to 10 additional mutations, including one known as "African," detected primarily in black populations. It therefore did not restrict representation of the disease to its "Caucasian" varieties, though whitesare much more likely to have the disease.

viii The metaphor of pastoral power is Foucault's. It designates a type of power oriented both toward the flock as a whole and each animal of which it is composed. 
${ }^{i x}$ In this sense, the AFDPHE debates were similar to those noted for other screening programs; e.g., mammography, characterized by tension between the orientations of epidemiologists, who were concerned about the various problems raised by the procedure (cost, women's anxiety, etc.), and clinicians, concerned not to let any cancer cases go undetected (Kaufert, 2000).

${ }^{\mathrm{x}}$ Information from the "Rapport sur la situation de la mucoviscidose en France en 2000," published by the Observatoire National de la Mucoviscidose, ONM (2002).

${ }^{x i}$ In a text written in 1967 that he consented to have published in 1984, Foucault (1994) wrote: "I think the focus of worry at this time is probably more fundamentally related to space than time."

${ }^{\text {xii }}$ Government decree (circulaire) DHOS-DGS no. 502 of October 22, 2001. 